\title{
8 nommbalina \\ Aliens \& Flames: a new research initiative joining fire behaviour and invasion ecology
}

\begin{tabular}{|c|c|}
\hline Autor(es): & $\begin{array}{l}\text { Silva, Joaquim S.; Deus, Ernesto; Nereu, Mauro; Davim, David A.; } \\
\text { Rossa, Carlos G. }\end{array}$ \\
\hline Publicado por: & Imprensa da Universidade de Coimbra \\
\hline $\begin{array}{l}\text { URL } \\
\text { persistente: }\end{array}$ & URI:http://hdl.handle.net/10316.2/44659 \\
\hline DOI: & DOI:https://doi.org/10.14195/978-989-26-16-506_142 \\
\hline Accessed : & 26-Apr-2023 02:35:27 \\
\hline
\end{tabular}

A navegação consulta e descarregamento dos títulos inseridos nas Bibliotecas Digitais UC Digitalis, UC Pombalina e UC Impactum, pressupõem a aceitação plena e sem reservas dos Termos e Condições de Uso destas Bibliotecas Digitais, disponíveis em https://digitalis.uc.pt/pt-pt/termos.

Conforme exposto nos referidos Termos e Condições de Uso, o descarregamento de títulos de acesso restrito requer uma licença válida de autorização devendo o utilizador aceder ao(s) documento(s) a partir de um endereço de IP da instituição detentora da supramencionada licença.

Ao utilizador é apenas permitido o descarregamento para uso pessoal, pelo que o emprego do(s) título(s) descarregado(s) para outro fim, designadamente comercial, carece de autorização do respetivo autor ou editor da obra.

Na medida em que todas as obras da UC Digitalis se encontram protegidas pelo Código do Direito de Autor e Direitos Conexos e demais legislação aplicável, toda a cópia, parcial ou total, deste documento, nos casos em que é legalmente admitida, deverá conter ou fazer-se acompanhar por este aviso.

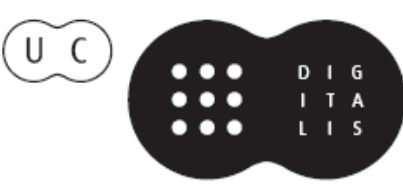




\section{ADVANCES IN}

\section{FOREST FIRE RESEARCH}

\section{8}

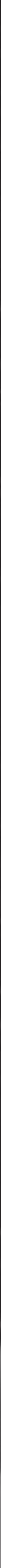


Short contribution - Fuel Management

Aliens \& Flames - a new research initiative joining fire behaviour and invasion ecology

Joaquim S. Silva*1,2; Ernesto Deus ${ }^{2}$; Mauro Nereu ${ }^{1}$; David A. Davim ${ }^{2,1}$; Carlos G. Rossa ${ }^{3}$

${ }^{1}$ College of Agriculture, Polytechnic Institute of Coimbra, 3040-316Coimbra, Portugal, \{jss@esac.pt*\}

${ }^{2}$ Centre for Applied Ecology 'Prof. Baeta Neves', School of Agriculture, University of Lisbon, 1349-017

Lisbon, Portugal

${ }^{3}$ Centre for Research and Technology of Agro-environmental and Biological Sciences (CITAB), University

of Trás-os-Montes e Alto Douro, Quinta de Prados, Apartado 1013, 5001-801 Vila Real, Portugal

\begin{abstract}
Wildfires and alien plant invasions are two major environmental concerns in Portugal. Some of the most aggressive invasive plant species are fire-adapted, which causes two problems: on one hand, wildfires may aggravate the invasions and promote the expansion of these species; on the other hand, the expansion of these plant species increases the risk of wildfires. This is the case of Acacia dealbata Link. and Hakea sericea Schrader, two species native to Australia that are problematic invaders in Portugal. Aliens \& Flames is an innovative approach which unites two branches of science that have been following two separate paths and have never been explored together in fire-adapted exotic plant species in Europe: fire behaviour and invasion ecology. This work provides insights into the Aliens \& Flames project, with a particular focus on the methodology and the expected results.
\end{abstract}

Keywords: alien invasive plants; prescribed fire; plant management; wildfires; Acacia dealbata; Hakea sericea

\title{
1. Introduction
}

\subsection{Wildfires and invasive plants in Portugal}

Wildfires are perhaps the most concerning environmental threat in Portugal, the European country most affected by wildfires and one of the most affected worldwide. Over the last decades, wildfires have been aggravating, ravaging Central Portugal particularly in 2017 (ICNF 2017). Alien invasive plants are another major environmental concern in Portugal. These invasions originate direct (e.g. production loss) and indirect costs (e.g. increased fire hazard, ecosystem degradation) and, unlike other degradation processes (e.g. forest fires, soil erosion), their effects are in many cases nearly irreversible (Moreira et al. 2010). Yearly, large amounts of money are spent in the control of plant invasions, which led to the establishment of specific legislation in Portugal (Decree-Law 565/99) and in the European Union (Regulation UE 1143/2014). Some of the most problematic invasive plants are adapted to fire. Frequently, fire facilitates plant invasions which in turn may facilitate fire spread, leading to a fireinvasion cycle (Brooks et al. 2004). In Portugal, Acacia dealbata Link. stands and Hakea sericea Schrader have expanded (ICNF 2013) as a result of the current fire regime (Marchante et al. 2014). Fire acts directly on the $A$. dealbata soil seed bank, stimulating germination, and the plant resprouts vigorously after canopy damage (Lorenzo et al.2010). There is also evidence of a strong relationship between $H$. sericea and fire. This serotinous obligate seeder spreads wind-dispersed seeds through fire-triggered dehiscence (Esler et al. 2009), leading to new invasion foci.

In this work, we present a new project started in 2018 that uses a new approach in Europe that addresses both problems - wildfires and plant invasions - by using fire to control fire-adapted invasive plant species. 


\subsection{Alien species and invasion dynamics}

\subsubsection{Target species}

Acacia dealbata is a tree up to 15 meters native to Southeast Australia and Tasmania. The flowers are bright-yellow. The fruits are brownish pods that mature yearly, releasing seeds between June and August (Northern hemisphere). Seeds $(4-5 \times 2.5 \mathrm{~mm}$ in size) are numerous, hard-coated and dormant, and form extensive soil seed banks that can remain viable for decades. Seeds bear an elaiosome, near half their size, highly attractive to ants that may disperse them (Montesinos et al., 2012). Although seeds are not adapted to wind dispersal, they may be transported by water and soil tillage.

Hakea sericea is a shrub or tree up to $4 \mathrm{~m}$, with irregular canopy. The leaves are green to greyishgreen needle shape $(0.5-1.5 \mathrm{~mm}$ diameter $)$, evergreen, very robust and sharp. The flowers, appearing from January to April (Northern hemisphere) are white, bland and arranged in axillary fascicles of 17 flowers. The fruits are woody follicles $(3 \mathrm{~cm})$, dark brown with a patent crest and beak, having two black winged seeds. Dehiscence occurs after tissue necrosis, allowing the release of the seeds (Marchante et al. 2008).

\subsubsection{Invasion dynamics}

Acacia dealbata is invasive in several world regions, such as Asia, South Africa, New Zealand, USA, South America and Madagascar. In Europe, it was introduced by the end of the 18th century as an ornamental species and the first evidence of invasive behaviour occurred in mid-19th century in France. It is a very problematic species in some countries of the Mediterranean Basin (Lazzaro et al. 2014), including Portugal where it was introduced mainly to stabilize soils and as an ornamental. $A$. dealbata is a fire-adapted species with a wide distribution in Portugal. Adaptations include vigorous resprouting, after fire and an extensive soil seed bank triggered by high temperatures. Therefore, after wildfires most individuals survive and new individuals normally arise, invading new areas and replacing the native vegetation. As a consequence, A. dealbata forms dense, monospecific stands, with high fuel load, potentially increasing the risk of wildfires. Management of this species is very difficult, costly, and frequently unsuccessful, because most people cut the individuals that vigorously resprout after treatment.

Hakea sericea is invasive in South Africa (Esler et al. 2009) and Portugal (Marchante et al. 2014). The invasive success of $H$. sericea can be attributed to prolific seed production and serotinous habit. Wind-dispersed seeds are massively released following the death of parent plants by fire. Seeds usually fall within tens of meters away from the parent plant (Richardson et al. 1987), but some may be reach much greater distances, establishing new foci and complicating control (Moody and Mack 1988).

\section{The project}

\subsection{Aims and scope}

Aliens \& Flames is a five-year project run by the Polytechnic Institute of Coimbra. It is an innovative approach that gathers two branches of science that have been following separate paths and have never been explored together in fire-adapted, invasive vegetation in Europe: fire behaviour and invasion ecology.

Aliens \& Flames aims to help improving the control of two of the most concerning environmental threats in Portugal: wildfires and alien plant invasions. We will explore the use of prescribed fire to control and eradicate invasions of $A$. dealbata and $H$. sericea. The main objectives are: a) to provide tools that allow reducing the risk of invasion in areas where prescribed fire is applied to vegetation management to prevent wildfires; b) to improve an alternative technique to control plant invasions; c) to improve forecasting plant invasions in burnt areas; d) to elaborate accurate fuel models for areas invaded by the target species; e) to advise forest owners about the problem of plant invasions and the 
effects of wildfires on plant invasions. The project currently focuses on the two referred target species, but has the ambition of enlarging its scope and encompass other fire-adapted plant invaders.

\subsection{Methods and expected results}

A set of experimental burns will be conducted in invaded areas in Central Portugal (Figure 34), featuring different slash-and-burn treatments corresponding to distinct fire regimes. A comprehensive set of data will be collected before, during and after the burns, including floristic composition and vegetation structure, seed bank properties, plant demography, fire behaviour parameters, soil characterization, and post-fire erosion.

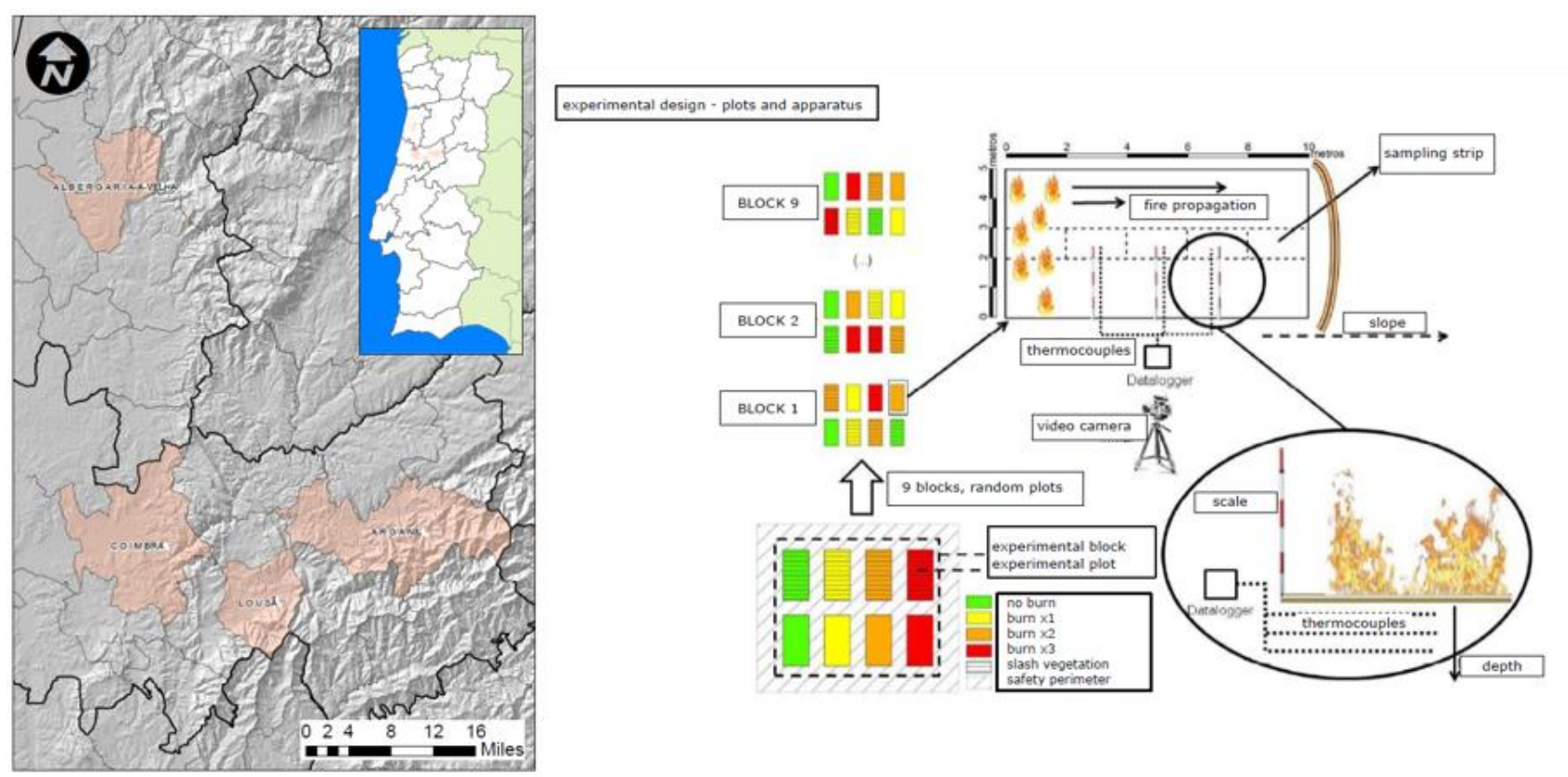

Figure 1 - Central Portugal study areas (left). Experimental design, treatment blocks and instrumentation (right).

Prior to the burns, the fuel complex at each plot will be characterized in order to develop fuel models representing the invaded areas. Plot treatments will allow testing different fire intensities and residence times, aimed at depleting the seed bank and eliminating alien plant individuals. During the burns meteorological parameters, such as air temperature and relative humidity, wind direction and speed, will be recorded using a portable weather station. Fire behaviour (e.g. rate of spread, flame geometry) will be recorded with a video camera, and the soil profile temperatures will be measured using a thermocouple array. First order fire effects will be assessed (e.g. fire severity, fuel consumption, soil heating) immediately after the burn. Plant demography (including native and alien plants), seed bank dynamics and soil erosion will be monitored along the entire project duration (five years).

Expected results, i.e. information on fire behaviour, vegetation dynamics and responses to fire, should provide the necessary knowledge to support fuel and fire management strategies and operations.

\section{Conclusion}

The results of this project will provide insights into the two-way relationships between two important invasive plant species and fire. This knowledge will allow a better management of these species through the use of prescribed burns. It will allow forecasting the extent of new invasions in burned areas and a better assessment of fire hazard in invaded areas. The infrastructure created by Aliens \& Flames through a network of experimental plots, is also an opportunity for collecting data on additional specific aspects of fire ecology, invasion ecology and fire behaviour. Therefore, we invite 
experts in these areas, interested in using this infrastructure for obtaining specific data, to contact the project leader (Joaquim S. Silva; jss@esac.pt) for future collaboration.

\section{References}

Brooks ML, D'Antonio CM, Richardson DM, Grace JB, Keeley JE, Di Tomaso JM, Hobbs RJ, Pellant M, Pyke D (2004) Effects of invasive alien plants on fire regimes. Bioscience 54:677-688.

Esler KJ, van Wilgen BW, te Roller KS, Wood AR, van der Merwe JH (2009) A landscape-scale assessment of the long-term integrated control of an invasive shrub in South Africa. Biological Invasions 12:211-218.

ICNF (2013) IFN6 - Áreas dos usos do solo e das espécies florestais de Portugal continental. Resultados preliminares. Instituto da Conservação da Natureza e das Florestas, Lisboa.

ICNF (2017) 10. ${ }^{\circ}$ Relatório Provisório de Incêndios Florestais - 2017: 01 de Janeiro a 31 de Outubro. Departamento de Gestão de Áreas Públicas e de Proteção Florestal. Instituto da Conservação da Natureza e das Florestas, Lisboa.

Lazzaro L, Giuliani C, Fabiani A, Agnelli AE, Pastorelli R, Lagomarsino A, Foggi B (2014) Soil and plant changing after invasion: The case of Acacia dealbata in a Mediterranean ecosystem. Science of the Total Environment 497:491-498. http://doi.org/10.1016/j.scitotenv.2014.08.014

Lorenzo P, González L, Reigosa MJ (2010) The genus Acacia as invader: the characteristic case of Acacia dealbata Link in Europe. Annals of Forest Science 67, 101.

Marchante E, Freitas H, Marchante H (2008) Guia prático para a identificação de plantas invasoras de Portugal Continental. Imprensa da Universidade de Coimbra, Coimbra.

Marchante H, Morais M, Freitas H, Marchante E (2014) Guia prático para identificação de plantas invasoras em Portugal. Imprensa da Universidade de Coimbra, Coimbra.

Moody ME, Mack RN (1988) Controlling the spread of plant invasions: the importance of nascent foci. Journal of Applied Ecology 25:1009-1021.

Montesinos D, Castro S, Rodríguez-Echeverría S, (2012) Invasive acacias experience higher ant seed removal rates at the invasion edges. Web Ecology 12:33-37.

Moreira F, Catry F, Silva JS, Rego F. (Eds.) (2010) Ecologia do fogo e gestão de áreas ardidas. ISAPress, Lisboa.

Richardson DM, van Wilgen BW, Mitchell DT (1987) Aspects of the reproductive ecology of four Australian Hakea species (Proteaceae) in South Africa. Oecologia 71:1432-1939. 